\title{
A EFICÁCIA HORIZONTAL DIRETA DOS DIREITOS FUNDAMENTAIS NO ÂMBITO DAS RELAÇÕES DE TRABALHO: O PAPEL DA NEGOCIAÇÃO COLETIVA NA IMPLEMENTAÇÃO DE AÇÕES AFIRMATIVAS DA DIGNIDADE DO TRABALHADOR
}

\author{
THE DIRECT HORIZONTAL EFFICACY OF FUNDAMENTAL RIGHTS IN THE CONTEXT OF \\ LABOR RELATIONS: THE ROLE OF COLLECTIVE NEGOTIATION IN THE IMPLEMENTATION OF \\ AFFIRMATIVE ACTIONS OF WORKER'S DIGNITY
}

\author{
Rodrigo Goldschmidt ${ }^{1}$ \\ Rodrigo Espiúca dos Anjos Siqueira²
}

\begin{abstract}
Resumo: Neste artigo analisa-se a implementação de ações afirmativas pelas empresas empregadoras e sindicatos obreiros, mediante a negociação coletiva como forma de concretização da dignidade do trabalhador sob as perspectivas objetiva e subjetiva dos direitos fundamentais sociais. Nessa tarefa, apresenta-se o conceito de direitos fundamentais e sua relação com a dignidade da pessoa humana. $\mathrm{Na}$ sua segunda parte, analisam-se as teorias sobre a eficácia dos direitos fundamentais, em suas dimensões vertical e horizontal. Em seguida, apresenta-se o conceito de ações afirmativas da dignidade da pessoa humana como medidas de concretização da dignidade, para, ao final, apresentar exemplos de normas coletivas que afirmam, concretamente, a dignidade do trabalhador, no âmbito da eficácia horizontal dos direitos fundamentais nas relações entre particulares de forma direta e imediata. A metodologia do estudo é a analítica-interpretativa de investigação bibliográfica e documental. Por método, adotou-se o indutivo.
\end{abstract}

Palavras-chave: Eficácia horizontal. Direitos fundamentais. Ações afirmativas. Negociação coletiva. Dignidade humana.

\begin{abstract}
The article analyzes the implementation of affirmative actions by employers' and workers' unions, through collective bargaining as a way of achieving the dignity of workers under the objective and subjective perspectives of fundamental social rights. In this task, it presents the concept of fundamental rights and their relationship with the dignity of the human person. In its second part, it analyzes the theories on the effectiveness of fundamental rights, in their vertical and horizontal dimensions. Then, it presents a concept of affirmative actions of the dignity of the human person as measures for the realization of dignity, in order to present examples of collective norms that concretely affirm the dignity of the worker within the framework of the horizontal effectiveness of fundamental rights in relations between private individuals directly and immediately. The methodology of the study is the analytical-interpretative of bibliographic and documentary research. As a method, the inductive was adopted.
\end{abstract}

Keywords: Horizontal efficacy. Fundamental rights. Affirmative actions. Labor negotiations. Human dignity.

\footnotetext{
Pós-Doutor em Direito pela Pontifícia Universidade Católica do Rio Grande do Sul; Doutor em Direito pela Universidade Federal de Santa Catarina; Professor e Pesquisador no Programa de Pós-Graduação em Direito da Universidade do Extremo Sul Catarinense; Juiz Titular da Vara do Trabalho de Araranguá, SC; rodrigo.goldschmidt@trt12.jus.br

2 Mestre em Direitos Fundamentais pela Universidade do Oeste de Santa Catarina; doutorando no Programa de Pós-Graduação em Direito da Universidade Federal do Rio Grande do Sul; Professor na Faculdade Anglicana de Erechim, Departamento de Pós-Graduação, Pesquisa e Extensão, Avenida Sete de Setembro, 44, Centro, 99700-300, Erechim, Rio Grande do Sul, Brasil; espiuca@yahoo.com
} 


\section{Introdução}

Os direitos fundamentais têm recebido tratamento distintivo nas constituições modernas. Assumem tal relevância a ponto de irradiar seus efeitos para todo o ordenamento jurídico do Estado Constitucional.

Contudo, o problema que se põe não é o do seu reconhecimento jurídico, mas, sim, o da sua eficácia concreta. Esse problema se revela em ambas dimensões sob as quais são compreendidos os direitos fundamentais, a saber: a dimensão subjetiva, que ampara o cidadão na sua individualidade e perante o Estado; e a dimensão objetiva, a qual valoriza o ponto de vista da sociedade, da comunidade na sua integralidade, nas ocasiões em que tais direitos fundamentais ultrapassarem a esfera individual em relação a direitos ou deveres.

Apesar da consolidação das normas de direitos fundamentais no seio das constituições, ainda há muito que se fazer para lhes dar eficácia concreta de forma a produzirem efeitos nas relações sociais cotidianas.

Afirma-se a eficácia direta de tais direitos quando as relações são entabuladas entre o Estado e o indivíduo. Nesse ponto quase não há disputa. No entanto, quando são apenas particulares os sujeitos que se relacionam, ainda existem posições dissonantes, ainda que minoritárias. Isso é especialmente verdade no que tange às relações de trabalho.

$\mathrm{Na}$ presente pesquisa tem-se por objetivo analisar as ações afirmativas da dignidade da pessoa humana, realizadas no âmbito da iniciativa privada, por intermédio da negociação coletiva, estabelecendo medidas de concretização desse relevante princípio constitucional, que preside os direitos fundamentais.

Nessa tarefa, o trabalho desenvolve-se em três partes: a primeira é dedicada à análise do conceito de direitos fundamentais e à relevância do princípio da dignidade da pessoa humana; a segunda trata de conceituar as várias teorias a respeito da eficácia dos direitos fundamentais, em suas dimensões vertical e horizontal; e na terceira, por sua vez, apresenta-se conceito - mais amplo que o tradicional, registre-se - de ações afirmativas da dignidade da pessoa humana, de forma a incluir também as ações promovidas e implementadas pela iniciativa privada, seja na ausência seja na complementação da ação estatal, e evidencia a essencialidade de tais ações afirmativas privadas, produzidas de maneira autônoma entre as partes envolvidas nas relações de trabalho, mediante o protagonismo das entidades sindicais obreiras e patronais, para a concretização da dignidade da pessoa humana nas relações de trabalho.

A metodologia empregada nesta pesquisa é a analítica-interpretativa de investigação bibliográfica e documental. No tocante ao método, optou-se pelo indutivo. 


\section{Direitos fundamentais: conceitos e relação com a dignidade da pessoa humana}

De início, cumpre destacar que a expressão "direitos fundamentais" foi utilizada pela primeira vez na França em 1770, na alvorada do movimento político e cultural que culminou com a Declaração dos Direitos do Homem e do Cidadão de 1789. Esse conceito obteve, rapidamente, grande importância na Alemanha, sob a denominação de Grundrechte, e lá fundamentou a organização do sistema de relações entre Estado e particulares, como base de toda a ordem jurídica e política (LUÑO, 2005).

Os direitos fundamentais e os direitos humanos estão intimamente ligados, uma vez que aqueles são, de fato, direitos humanos positivados na ordem jurídica de um Estado Constitucional. É esse o entendimento atribuído aos direitos fundamentais e utilizado neste trabalho. Direitos fundamentais são, portanto, verdadeiros direitos humanos que adquirem caráter fundamental ao serem positivados na ordem jurídica interna de uma nação mediante sua inclusão na constituição daquele Estado. ${ }^{3}$

Recentemente, autores como Luño têm proposto uma ampliação da compreensão de direitos fundamentais, que, dessa forma, passariam a ser compreendidos como a síntese das liberdades individuais, resultado dos direitos políticos e das demandas sociais resultantes de uma compreensão do caráter institucional do direito. Assim se expressa Luño (2005, p. 25, tradução nossa):

No horizonte do constitucionalismo atual os direitos fundamentais desempenham, portanto, uma dupla função: no plano subjetivo seguem atuando como garantias das liberdades individuais, se bem que a este papel clássico se une agora a defesa dos aspectos sociais e coletivos da subjetividade, ao passo que no plano objetivo assumiram uma dimensão institucional a partir da qual o seu conteúdo deve funcionalizar-se para a consecução dos fins e valores constitucionalmente proclamados. $^{4}$

Contudo, para os fins a que se destina o presente trabalho, e conforme referido anteriormente, a distinção entre direitos humanos e direitos fundamentais aqui adotada é aquela defendida por Sarlet (2011a, p. 32), assim formulada:

Neste sentido, os direitos humanos (como direitos inerentes à própria condição e dignidade humana) acabam sendo transformados em direitos fundamentais pelo modelo positivista, incorporando-os ao sistema de direito positivo como elementos essenciais, visto que apenas mediante um processo de "fundamentalização" (precisamente pela incorporação às constituições) os direitos naturais e inalienáveis da pessoa adquirem a hierarquia jurídica e seu caráter vinculante em relação a todos os poderes constituídos no âmbito e um Estado Constitucional.

\footnotetext{
3 A respeito, vale conferir Miranda (2012, p. 14-15).

4 No original: "En el horizonte del constitucionalismo actual los derechos fundamentales desempeñan, por tanto, una doble función: en el plano subjetivo siguen actuando como garantías de la libertad individual, si bien a este papel clásico se aúna ahora la defensa de los aspectos sociales y colectivos de la subjetividad, mientras que en el objetivo han asumido una dimensión institucional a partir de la cual su contenido debe funcionalizarse para la consecución de los fines y valores constitucionalmente proclamados." (LUÑO, 2005, p. 25).
} 
A relevância de se fazer a clara distinção entre direitos humanos e direitos fundamentais, especialmente no Brasil, se manifesta no resultado prático de classificar um direito como fundamental, o que permite uma melhor efetivação e proteção judicial. Para Marmelstein (2014, p. 15, grifo do autor), os direitos fundamentais, no Brasil:

Possuem aplicação imediata, por força do art. $5^{\circ}, \mathbb{S} 1^{\circ}$, da Constituição de 88, e, portanto, não precisam de regulamentação para serem efetivados, pois são diretamente vinculantes e plenamente exigíveis;

São cláusulas pétreas, por força do art. $60, \$ 4^{\circ}$, inc. IV, da Constituição de 88 , e, por isso, não podem ser abolidos nem mesmo por meio de emenda constitucional; Possuem hierarquia constitucional, de modo que, se determinada lei dificultar ou impedir, de modo desproporcional, a efetivação de um direito fundamental, essa lei poderá ter sua aplicação afastada por inconstitucionalidade.

Assim, importante é a distinção entre direitos humanos e direitos fundamentais pela aplicação imediata e eficácia atribuída a estes, bem como para uma melhor proteção e concretização de seus postulados, ainda que seja necessário lançar mão do poder judiciário para tanto.

Dadas as características citadas, pode-se entender que os direitos fundamentais são essenciais para uma vida digna em sociedade. Em outras palavras, "a dignidade humana é, portanto, a base axiológica desses direitos." (MARMELSTEIN, 2014, p. 16).

Por conseguinte, é possível afirmar que a base ética e o conteúdo valorativo dos direitos fundamentais consiste em garantir à pessoa humana a proteção e concretização de sua dignidade.

A respeito, vale ter em conta a lição de Hesse (2009, p. 33):

Os direitos fundamentais devem criar e manter as condições elementares para assegurar uma vida em liberdade e a dignidade humana. Isso só se consegue quando a liberdade da vida em sociedade resulta garantida em igual medida que a liberdade individual. Ambas se encontram inseparavelmente relacionadas. A liberdade do indivíduo só se pode dar numa comunidade livre, e vice-versa; essa liberdade pressupõe seres humanos e cidadãos com capacidade e vontade para decidir por si mesmos, sobre seus próprios assuntos e para colaborar responsavelmente na vida da sociedade publicamente constituída como comunidade.

Goldschmidt (2009, p. 66) realça a relevância da dignidade para o ordenamento jurídico, afirmando a sua posição de fundamento da República Federativa do Brasil:

Em função da extrema importância, a dignidade da pessoa humana foi erigida pelos legisladores constituintes à condição de fundamento da República Federativa do Brasil. Isso denota que o sistema jurídico brasileiro, capitaneado pela Constituição da República Federativa do Brasil, revestiu a dignidade da pessoa humana de juridicidade, constituindo-a como principal alicerce da sua estrutura. Sobre esse sistema repousa toda a plêiade de direitos fundamentais, individuais e sociais do homem.

Com isso, a dignidade da pessoa humana, para além de ser um fundamento ético da República brasileira, constitui-se em uma categoria jurídica fundamental, re- 
vestida de normatividade a garantir plena eficácia na realidade concreta da vida das pessoas em sociedade..$^{5}$

Por seu turno, e na mesma linha, Andrade (2009, p. 66) destaca:

Realmente, o princípio da dignidade da pessoa humana (individual) está na base de todos os diritos constitucionalmente consagrados, quer por direitos e liberdades tradicionais, quer dos direitos a prestações sociais. É dizer que a dignidade humana se projecta no indivíduo enquanto ser autónomo, em si e como membro da comunidade - são direitos da pessoa, do cidadão, do trabalhador e do administrado.

Pode ser diferente o grau de vinculação dos direitos àquele princípio. Assim, alguns direitos constituem explicitações do primeiro grau da ideia de dignidade, que modela todo o conteúdo deles: o direito à vida, à identidade e à integridade pessoal, à liberdade física e de consciência, por exemplo, tal como a generalidade dos direitos pessoais, são atributos jurídicos essenciais da dignidade dos homens concretos. Outros direitos decorrem desse conjunto de direitos fundamentalíssimos (diríamos, com o sentido e com as reservas atrás expostas, direitos naturais) ou então completam-nos como explicitações de segundo grau, mediadas pela particularidade das circunstâncias sociais e económicas, políticas e ideológicas: o conteúdo do direito de resposta, da liberdade de empresa, do direito a férias pagas, dos direitos à habitação, à saúde, à segurança social e à cultura dependem de opções políticas estruturais e até, por vezes, de estratégias conjunturais, Mas, ainda aí, é o princípio da dignidade da pessoa humana que está, nos tempos actuais, na raiz da sua previsão constitucional e da sua consideração como direitos fundamentais.

Contudo, difícil é a tarefa de definir, com clareza e assertividade, em que consiste a dignidade da pessoa humana. Sarlet (2011b) afirma que se torna mais fácil definir dignidade quando se vislumbra uma violação desta.

O autor apresenta uma compreensão da dignidade como a vedação contra a instrumentalização da pessoa humana, e assim se expressa nesse sentido:

Ainda nesta perspectiva, já se apontou - com razão, no nosso sentir - para o fato de que o desempenho das funções sociais em geral encontra-se vinculado a uma recíproca sujeição, de tal sorte que a dignidade da pessoa humana, compreendida como a vedação da instrumentalização humana, em princípio proíbe a completa e egoística disponibilização do outro, no sentido de que se está a utilizar outra pessoa apenas como meio para alcançar determinada finalidade, de tal sorte que o critério decisivo para a identificação de uma violação da dignidade passa a ser (pelo menos em muitas situações, convém acrescer) o do objetivo da conduta, isto é, a intenção de instrumentalizar (coisificar) o outro. (SARLET, 2011b, p. 63).

Pode-se afirmar, diante do anteriormente asseverado, que a dignidade da pessoa humana pode ser entendida como aquela característica inerente ao ser humano, e que impede a identificação da pessoa com mero objeto, de forma a sujeitá-la à vontade alheia como se instrumento fosse, desconsiderando o seu status de sujeito de direitos e transformando-a em objeto dos desígnios de outrem.

\footnotetext{
5 Para um estudo aprofundado sobre a dignidade da pessoa humana sob as óticas da Filosofia e da Ciência Política, bem como para uma visão analítica desta mesma dignidade como princípio jurídico basilar no ordenamento jurídico brasileiro, e em sua dimensão protetiva e prestacional, ver o Capítulo I da obra: Flexibilização dos direitos trabalhistas: Ações afirmativas da dignidade como forma de resistência. São Paulo: LTr, 2009, de Rodrigo Goldschmidt.
} 
Nessa linha, apresenta-se relevante a lição de Novais (2006, p. 30-31):

O princípio da dignidade da pessoa humana acaba, assim, por constituir o fundamento da concepção dos direitos como trunfos, porque é dessa igual dignidade de todos que resulta o direito de cada um conformar autonomamente a existência segundo as suas próprias concepções e planos de vida que têm, à luz do Estado de Direito fundado na dignidade da pessoa humana, o mesmo valor de quaisquer outras concepções ou planos de vida, independentemente da maior ou menor adesão social que concitem. Daí resulta a inadmissibilidade de a maioria política, mesmo quando formada democraticamente, impor ao indivíduo concepções ou planos de vida com que ele não concorde, por mais valiosas que essas concepções sejam tidas pela maioria. Essa tentativa seria, não apenas moral e politicamente inaceitável, como, sobretudo, e para o que aqui nos importa, juridicamente vedada, já que constituiria uma restrição do livre desenvolvimento da personalidade inadmissível à luz do princípio da dignidade da pessoa humana e, enquanto tal, constitucionalmente rejeitada.

Mesmo a sujeição voluntária e irrestrita - a se admitir que alguém, de livre e espontânea vontade, abrisse mão de seus direitos e desejasse colocar-se integralmente ao alvitre alheio, sem que sua condição de indivíduo fosse respeitada - não pode ser admitida diante da proeminência dos valores constitucionais, hierarquizados como vetores axiológicos máximos que irradiam sua influência sobre todo o ordenamento jurídico, atraindo a sujeição das demais regras e normas. Dessa forma, não será admitida, sob pena de violar a dignidade da pessoa humana, a criação de leis que retirem dos indivíduos a garantia e as proteções afetas à sua dignidade.

E é para a proteção da pessoa e de sua dignidade que o ordenamento jurídico deve ser orientado, formulado e interpretado. Deve-se levar em alta conta a garantia da concretização da dignidade da pessoa humana. Tais garantias devem ser concretizadas por meio de direitos e deveres correlatos e passíveis de serem aduzidos em juízo, se necessário for.

A propósito, Barbagelata (2009, p. 302) propõe as seguintes diretrizes constitucionais para proteção dos direitos fundamentais do trabalhador no âmbito das relações de trabalho:

a) Reconhecimento de que, (como consta na Declaração de Viena de 1993): “Todos os direitos humanos tem origem na dignidade e no valor da pessoa humana... (porque esta) deve ser a principal beneficiária desses direitos e liberdades"; b) Deve-se atribuir idêntico valor jurídico a todas as disposições que integram o bloco de constitucionalidade dos direitos humanos, sem prejuízo de que, para sua efetividade em alguns casos seja preciso contar com normas de infraestrutura complementares; c) Dada a identificação do trabalho com a pessoa do trabalhador, esta deve estar resguardada por uma proteção especial da lei, a qual seria diretamente válida, na maioria dos casos, em detrimento dos direitos emanados da propriedade; d) As disposições sobre trabalho que integram o bloco de constitucionalidade não só contemplam obrigações para os Estados, mas também direitos e obrigações que cobrem as relações entre os particulares. ${ }^{6}$

\footnotetext{
6 No original, em espanhol: "a) Reconocimiento de que, (como consta em la Declaración de Viena de 1993): 'Todos los derechos humanos tienen origen em la dignidad y el valor de la persona humana... [Por lo que ésta] debe ser la principal beneficiaria de esos derechos y libertades'; b) Debe atribuirse idéntico valor jurídico a todas las disposiciones que integram el loque de constitucionalidad de los derechos humanos, sin perjuício de que, para sua efectividad em algunos casos sea preciso contar con normas o infraestructuras complementarias; c) Dada la identificación del trabajo com la persona do trabajador, ésta debe estar resguardada por una protección especial de laley, la cual sería directamente válida, em la mayoría de los casos, respecto de los derechos emanados de la propriedad; d) Las disposiciones sobre
} 
De outra banda, para Sarmento (2016, p. 92, grifo do autor), a dignidade da pessoa humana configura-se em princípio multifacetário insculpido na Constituição Federal de 1988 :

Dessa compreensão emergem, prima facie, os seguintes componentes do princípio da dignidade da pessoa humana: o valor intrínseco da pessoa que veda sua instrumentalização em proveito de interesses de terceiros ou de metas coletivas; a igualdade, que implica a rejeição das hierarquias sociais e culturais e impõe que se busque a sua superação concreta; a autonomia, tanto na sua dimensão privada, ligada à autodeterminação individual, como na pública, relacionada à democracia; o mínimo existencial, que envolve a garantia das condições materiais indispensáveis para a vida digna; e o reconhecimento, que se conecta com o respeito à identidade individual e coletiva das pessoas nas instituições, práticas sociais e relações intersubjetivas.

Percebe-se, na definição proposta, que a dignidade é um objeto composto e múltiplo, não monolítico, que se manifesta nas várias facetas da vida em sociedade, tanto na esfera pública quanto na privada; tanto em face do Estado quanto diante de particular.

Sarmento (2016), contudo, alerta para o fato de que a dignidade não encontra na Constituição de 1988 um único dispositivo que lhe garanta na sua integridade multifacetária. Os direitos fundamentais protegem apenas aspectos da dignidade, de forma fragmentária, pois não há "qualquer direito específico que abarque, em toda a sua extensão, o valor intrínseco da pessoa." (SARMENTO, 2016, p. 92).

Pelo que se faz necessário estudar, com profundidade, o tema da proteção à dignidade, bem como seus atores e responsáveis, de forma a fornecer subsídio teórico e prático à sua concretização.

Sarlet (2011b, p. 65-66, grifo do autor), apoiando-se em Gonçalves Loureiro, assim se posiciona a respeito da relevância da proteção à dignidade e suas condições práticas:

De qualquer modo, o que importa, nesta quadra, é que se tenha presente a circunstância, oportunamente destacada por Gonçalves Loureiro, de que a dignidade da pessoa humana - no âmbito de sua perspectiva intersubjetiva - implica uma obrigação geral de respeito pela pessoa (pelo seu valor intrínseco como pessoa), traduzida em um feixe de deveres e direitos correlativos, de natureza não meramente instrumental, mas sim, relativos a um conjunto de bens indispensáveis ao "florescimento humano".

Note-se que a promoção e concretização da dignidade devem ocorrer não apenas na elaboração, interpretação e aplicação das leis por parte do Estado, mas também, e talvez, em alguns casos, principalmente, nas relações intersubjetivas (tema que será novamente abordado e aprofundado mais adiante), pelo que o Estado deve se ocupar de garantir que os indivíduos também respeitem e promovam a dignidade da pessoa humana.?

e ltrabajo que integram el bloque de constitucionalidad no sólo contemplan las obligaciones para los Estados, sino derechos y obligaciones que cubrenlas relaciones entre los particulares."

7 É o que Sarlet descreve como a condição limite e tarefa, ou dimensão defensiva e prestacional, da dignidade humana. Na condição limite, a dignidade deve servir para refrear a atividade estatal potencialmente ou efetivamente lesiva, e, na condição 
Essa afirmação se deve ao que se convencionou chamar de dupla dimensão desses direitos. Os direitos fundamentais vinculam-se à dimensão subjetiva (aquela relativa ao indivíduo em sua singularidade e nas relações perante o Estado) e à dimensão objetiva (que diz respeito à compreensão social, coletiva, das regras jusfundamentais, quando estas dizem respeito aos valores e fins que transcendem a esfera do indivíduo, seja em relação a direitos ou obrigações (SARLET, 2011a, p. 141).

Hesse (1998 p. 228) corrobora com essa compreensão e afirma serem os direitos fundamentais direitos subjetivos, direitos do indivíduo, mas que, por outro lado, também são "elementos fundamentais da ordem objetiva da coletividade."

Canotilho (1991, p. 114), na mesma linha de pensamento, referindo-se à fundamentação dos direitos fundamentais, afirma esta ser subjetiva quando consagrar um direito dirigido aos interesses do particular, afetando sua situação de vida, sua liberdade, por exemplo; e diz ser objetiva quando o direito fundamental for analisado em relação à coletividade, ao interesse público, à vida comunitária, ou como um valor geral que interesse a todas as pessoas.

Essa constatação da dupla dimensão, ou fundamentação, dos direitos fundamentais eleva a discussão a respeito da vinculação de tais direitos, pois os eleva da condição meramente individual e subjetiva ao patamar de verdadeira ordem objetiva de valores da coletividade, impondo-os de forma geral e irrestrita a todos os atores sociais, públicos ou privados.

A sociedade deve, portanto, organizar-se de maneira a concretizar cada vez mais tais direitos insculpidos na ordem jurídica constitucional. E essa tarefa não é exclusiva do Estado e não pode ser entendida apenas nos moldes da edição de leis ou mediante atividades administrativas prestacionais de garantia dos direitos sociais, mas, sim, como dever de todos, agentes públicos ou privados.

Alexy (2003) afirma que existem duas principais construções de direitos constitucionais: uma estrita (narrow and strict) e outra mais ampla (broad and comprehensive). A primeira é chamada de construção da regra (rule construction), e a segunda, a construção do princípio (principle construction). $O$ autor alemão afirma, ainda, que nenhuma das duas é utilizada em sua forma pura, mas representam diferentes tendências, asseverando que a definição de qual delas é a melhor depende da interpretação de cada constituição e deve prover meios para a revisão constitucional. Para o autor, a construção estrita compreende as normas que atribuem direitos constitucionais como indistintas das demais normas, apesar de sua alta hierarquia normativa, e que prestam à defesa de direitos abstratos (highly abstract rights) dos cidadãos, protegendo-os, de forma abstrata, contra o Estado. A construção ampla, por sua vez, atribui às normas de direito constitucional a característica de proteger o cidadão em um quadro mais amplo do que meramente abstrato (ALEXY, 2003, p. 131-132).

Os indivíduos, dessa forma, inserem-se nesse quadro mais amplo de garantia de direitos constitucionais e, também em suas relações cotidianas intersubjetivas, estão adstritos às regras jusfundamentais e devem, por essa razão, encetar ações que tenham o condão de não violar e, indo

tarefa, o Estado deve movimentar-se (prestação) para garantir essa mesma dignidade (SARLET, 2011b, p. 58-62). 
além, de gerar condições concretas para o usufruto e promoção de tais direitos fundamentais, como decorrência da dupla dimensão subjetiva e objetiva.

Por todo o exposto, pode-se afirmar que a dignidade da pessoa humana é, então, a base axiológica dos direitos fundamentais, ao mesmo tempo em que determina a orientação do ordenamento jurídico para a sua proteção e concretização, demandando do Estado, e também dos particulares, omissões (de violação) e ações concretas de efetivação de seu conteúdo.

É nesse segundo aspecto (intersubjetivo) da dignidade, isto é, nas relações entre particulares, que se insere o tema central do presente trabalho, mais especificamente nas relações de trabalho, em que os sujeitos estão objetivamente alinhados, porém díspares em condições subjetivas e potencialidades.

\section{A eficácia dos direitos fundamentais: a questão da vinculação dos particulares}

Várias são as teorias sobre a eficácia dos direitos fundamentais. ${ }^{8}$ A partir de agora, abordam-se as principais teorias sobre a eficácia de tais direitos, indicando-se a opção adotada na presente pesquisa.

Há teorias sobre a eficácia puramente vertical (aquela atinente às relações entre Estado e indivíduos) e outras sobre a possibilidade de conferir eficácia também às relações intersubjetivas, isto é, de que os direitos fundamentais também vinculam as ações dos particulares nas relações com outros indivíduos.

A eficácia vertical dos direitos fundamentais é aquela dirigida exclusivamente ao Estado, quando este se relaciona com os indivíduos. Isso quer dizer que o Estado deve, ao exercer a atividade administrativa ou legislativa, respeitar os direitos fundamentais.

A respeito, Marmelstein (2014, p. 337) assevera:

Como se sabe, os direitos fundamentais foram concebidos, originariamente, como instrumentos de proteção dos indivíduos contra a opressão estatal. O particular era, portanto, o titular dos direitos e nunca o sujeito passivo. É o que se pode chamar de eficácia vertical dos direitos fundamentais, simbolizando uma relação (assimétrica) de poder em que o Estado se coloca em posição superior em relação ao indivíduo.

Nesse sentido, para dar efetividade aos direitos dos indivíduos, o Estado deve adotar medidas concretas de efetivação e proteção da dignidade da pessoa humana, como resultado da vinculação dos seus agentes e atos aos direitos fundamentais.

Pode-se afirmar isso em decorrência da condição de norma constitucional dos direitos fundamentais, conforme se depreende da lição de Sarlet (2011a, p. 271):

8 Essas teorias foram mais detidamente abordadas em: Siqueira e Wenczenovicz (2016a, p. 373-397, 2016b, p. 290-310, 2017, p. 202-222). 
Se, portanto, todas as normas constitucionais sempre são dotadas de um mínimo de eficácia, no caso dos direitos fundamentais, à luz do significado outorgado ao art. $5^{\circ}, \mathbb{S} 1^{\circ}$, de nossa Lei Fundamental, pode-se afirmar que aos poderes públicos incumbem a tarefa e o dever de extrair das normas que os consagram (os direitos fundamentais) a maior eficácia possível, outorgando-lhes, neste sentido, efeitos reforçados relativamente às demais normas constitucionais, já que não há como desconsiderar a circunstância de que a presunção de aplicabilidade imediata e plena eficácia que milita em favor dos direitos fundamentais constitui, em verdade, um dos esteios de sua fundamentabilidade formal no âmbito da Constituição.

Assim, a eficácia vertical dos direitos fundamentais configura-se na possibilidade de o cidadão invocar a aplicação de tais direitos, de forma imediata, na hipótese de uma ação ou omissão estatal, seja para cessar a ameaça ou violação, seja para demandar uma prestação.

No que se refere à eficácia horizontal dos direitos fundamentais, quer dizer, a possibilidade de se opor os mencionados direitos nas relações entre particulares, em que o Estado não participa diretamente, a problemática ocorre justamente na possibilidade ou não de invocação dos direitos fundamentais.

Em outras palavras, faz-se necessário analisar se as ações dos indivíduos estão ou não vinculadas aos princípios e ditames constitucionais dos direitos fundamentais. Nesse sentido, algumas teorias, como se verá a seguir, abordam a mencionada eficácia horizontal.

A primeira delas é a teoria da eficácia mediata ou indireta. Essa teoria é oriunda da Alemanha e foi desenvolvida por Günther Dürig, na década de 1950. Seu exemplo mais significativo e emblemático é o Caso Lüth, de 1958.

Steinmetz (2004, p. 138-193) assim se pronuncia sobre a teoria da eficácia indireta:

Para a teoria da eficácia mediata, os direitos fundamentais não incidem nas relações entre particulares como direitos subjetivos constitucionais, mas como normas objetivas de princípio (princípios objetivos) ou, para usar uma terminologia a teoria axiológica dos direitos fundamentais, como sistema de valores (Wert system) ou uma ordem objetiva de valores. Isso apareceu expressamente na construção do Tribunal Constitucional alemão na decisão do Caso Lüth.

Para o autor, a referida teoria afirma os direitos fundamentais como ordem objetiva de valores, aos quais se subordinam o Estado e os particulares, concedendo a tais direitos proeminência na ordem jurídica interna de forma a impregnar todo o ordenamento jurídico que deve se conformar aos seus ditames em todos os seus aspectos.

Dessa forma, os direitos fundamentais seriam direitos prima facie de liberdade e, por isso mesmo, podem ser opostos diretamente contra atos do Estado, mas não deveriam obter eficácia direta contra os atos de particulares, uma vez que ambos os envolvidos nas relações intersubjetivas são detentores de direitos fundamentais, ao passo que o Estado não o é (STEINMETZ, 2004).

A aplicabilidade dos direitos fundamentais às relações intersubjetivas, para a teoria da eficácia mediata ou indireta, se realiza por meio da mediação legislativa ou judicial do Estado. Segundo Marmelstein (2014, p. 342): "Essa ideia vigora, por exemplo, na Alemanha, que entende que a lei é 
o principal instrumento normativo para a regulação das relações entre os particulares, devendo a Constituição ser utilizada de modo meramente subsidiário."

Dessa forma, o Estado, por intermédio de sua atividade legislativa, deve criar as leis de direito privado e, através de sua atividade judicante, aplicar tais normas de forma a modular a eficácia dos direitos fundamentais nas relações intersubjetivas.

A par desta, tem-se a teoria da eficácia imediata ou direta, preconizada por Hans Karl Nipperdey e empregada pelo Tribunal Federal do Trabalho alemão, também na década de 1950; essa teoria proclama a aplicação sem mediação da eficácia dos direitos fundamentais às relações intersubjetivas.

Steinmetz (2004) refere que à época do seu surgimento essa teoria demandava, para que houvesse a eficácia imediata, a atribuição de um status especial a um dos interlocutores jurídicos em face aos demais sujeitos.

Em termos contemporâneos, contudo, a teoria da eficácia imediata não mais exige desigualdade entre os partícipes no âmbito privado, já que tais direitos passam a ser compreendidos como determinações constitucionais dirigidas ao Estado e aos particulares, a despeito de sua condição pessoal, qualquer que seja (STEINMETZ, 2004, p. 165).

Uma vez que os direitos fundamentais ostentam a condição de norma constitucional positiva, irradiam seus efeitos a toda a ordem jurídica interna, e não devem, portanto, estar restritos às atividades legislativa ou judicial do Estado, mas regem também as relações entabuladas entre os particulares, sem a necessidade de mediação da lei ou do juiz.

Steinmetz (2004, p. 167) assim descreve a teoria da eficácia direta ou imediata:

Postula-se por uma eficácia não condicionada à mediação concretizadora dos poderes públicos, isto é, o conteúdo, a forma e o alcance da eficácia jurídica não dependem de regulações legislativas específicas nem de interpretação e de aplicações judiciais, conforme aos direitos fundamentais, de textos e normas imperativas de direito privado, de modo especial, daqueles portadores de cláusulas gerais.

Portanto, a teoria da eficácia imediata prega a desnecessidade da mediação estatal para a vinculação dos particulares aos direitos fundamentais e afirma, sob o argumento da força hierárquica constitucional, a possibilidade de invocar, direta e imediatamente, tais direitos nas relações intersubjetivas.

De acordo com Marmelstein (2014, p. 342), a eficácia horizontal implica que "os direitos fundamentais devem ser aplicados de forma direta às relações entre particulares, da mesma forma como são aplicados na relação entre o Estado e os indivíduos, ainda que com temperamentos." No Brasil, segundo o mencionado autor, "essa possibilidade vem ganhando cada vez mais força na doutrina e na jurisprudência e parece ser a mais adequada ao espírito da Constituição Federal de 1988." 
A título de mero registro, existem, também, teorias que negam a eficácia horizontal dos direitos fundamentais, são elas: A teoria de Schwabe e a da StateAction ${ }^{10}$ (também chamada de ação estatal). Essas teorias não serão aqui tratadas, pois não integram o escopo da presente pesquisa.

Antes de encerrar, e para não passar em branco no debate, Alexy (2011) propõe um modelo integrador. Segundo ele, é possível e desejável a integração entre os modelos da eficácia direta, da eficácia indireta e da negação (Schwabe). Afirma o autor em tela que somente por meio da integração das mencionadas teorias é que o aplicador do direito pode oferecer soluções viáveis para todas as aplicações dos direitos fundamentais.

Para Alexy (2011, p. 531), as teorias da eficácia imediata e mediata são dirigidas, em primeiro lugar, ao Poder Judiciário, e a teoria da negação ou da imputação (Schwabe) tem como alvo os Poderes Judiciário e Legislativo.

Ocorre que nenhuma das três teorias, por si só, consegue alcançar e solucionar todos os aspectos envolvidos em uma disputa de direitos fundamentais entre dois ou mais indivíduos, uma vez que todos são detentores de direitos fundamentais, pelo que deve a eficácia ser aplicada de forma ponderada, protegendo, assim, todos os direitos envolvidos (ALEXY, 2011, p. 533-542).

O modelo integrador proposto por Alexy tem o condão de atender, na opinião do autor, a qualquer demanda de direitos fundamentais entre particulares, conforme se depreende das assertivas a seguir:

Até agora a polêmica sobre os efeitos perante terceiros foi em geral travada como se uma das três construções tivesse que ser a correta. Essa hipótese é falsa. É possível afirmar que cada uma das três construções destaca alguns aspectos das complexas relações jurídicas que são características dos casos de efeitos perante terceiros, e que se torna inadequada apenas quando se pretende que o aspecto destacado seja tomado como a solução completa. Somente um modelo que abarque todos os aspectos pode oferecer uma solução completa, e, nesse sentido, adequada. Os marcos fundamentais de um tal modelo serão esboçados a seguir. O modelo é composto por três níveis: o do dever estatal, o dos direitos em face do Estado e o das relações jurídicas entre os sujeitos privados. Entre esses níveis não há uma relação de grau, mas de mútua implicação. (ALEXY, 2011, p. 533).

Dessa forma, poderia o modelo integrador de Robert Alexy resolver qualquer querela a respeito de colisão de direitos fundamentais, atendo-se ao objeto da disputa (dever estatal ou obrigação particular), aos interessados (os sujeitos da relação), ou ao destinatário da norma, conforme o caso.

\footnotetext{
9 Steinmetz (2004, p. 175-176) e Alexy (2011, p. 530-532) se referem a essa teoria como tendo sido criada por Jurgen Schwabe, na Alemanha de 1940, e que afirma negar a eficácia horizontal dos direitos fundamentais sob o argumento de que toda violação a direitos fundamentais é, em última instância, um resultado da permissão ou da não proibição estatal. O Estado, dessa forma, ao permitir ou não impedir a violação perpetrada pelo particular, comete, ele mesmo, a violação, e por isso o particular não pode ser responsabilizado pela violação ou ameaça aos direitos fundamentais.

10 Steinmetz (2004, p. 179) define essa teoria como aquela que, em primeira análise, nega a eficácia direta dos direitos fundamentais entre particulares e afirma que apenas o Estado é destinatário das normas de direitos fundamentais, mas que, na hipótese de existir uma demanda judicial entre indivíduos, na qual o Estado não é parte, realiza uma ampliação da abrangência da ação estatal e, dessa forma, oferece solução ao caso concreto sem ter que afirmar expressamente a eficácia horizontal. Essa teoria realiza, na verdade, uma conformação da ação individual à ação estatal, para, só aí, realizar a aplicação dos direitos fundamentais.
} 
Colocadas as múltiplas teorias sobre a eficácia dos direitos fundamentais no âmbito das relações privadas, tem-se que a mais adequada, nomeadamente no âmbito das relações de trabalho no Brasil, é aquela que preconiza a eficácia horizontal direta.

Reforçando esse entendimento, Ledur (2009, p. 41) assevera:

Na Constituição brasileira de 1988, grande inovação se deu com o reconhecimento, no art. $7^{\circ}$, de série de direitos fundamentais trabalhistas que são expressão de eficácia direta em face de particulares ou terceiros - empregadores ou tomadores de serviços. Além de originarem prestações obrigatoriamente integrantes dos contratos de emprego, esses direitos irradiam eficácia direta. Com base nela e em conexão com princípios fundamentais em geral justifica-se, em casos nos quais a justiça contratual for violada, que os contratos de emprego tenham seu conteúdo submetido ao controle judicial. Também o art. $8^{\circ}$, que garante a liberdade sindical, identifica-se eficácia direta contra terceiros que traduz a existência de direito subjetivo exercitável coletivamente. Além disso, outros direitos coletivos dos artigos $9^{\circ}$ e 11 podem ser compreendidos como direitos com eficácia direta contra terceiros. Os direitos sob exame também são protegidos contra intervenções estatais não fundadas na Constituição. Se violados, seja pelo Estado, seja por particulares, esses direitos conferem ao titular um direito de defesa exercitável perante o Poder Judiciário.

Nesse mesmo norte, e de forma igualmente ponderada, Amaral (2008, p. 267, grifo do autor) leciona:

Há que se mencionar, entretanto, que, mesmo para aquela corrente doutrinária que entende pela aplicação mediata ou indireta dos direitos fundamentais em relação às entidades privadas, torna-se frequente o reconhecimento no sentido de que, no campo das relações jurídico-privadas, em que existe uma clara situação de desigualdade das partes - tal como ocorre na relação mantida entre empregado e empregador -, deve-se abrir uma exceção, promovendo a aplicação de forma imediata ou direta dos direitos, liberdades e garantias previstas na Constituição.

Percebe-se, portanto, que somente por meio da aplicação direta e imediata dos direitos fundamentais nas relações trabalhistas será possível a efetiva proteção dos direitos e liberdades públicas dos trabalhadores, em face do dinamismo destas vinculações. Essa conclusão pode ser atribuída à intangibilidade do conteúdo essencial dos direitos fundamentais dos trabalhadores, e, ainda, diante da flagrante desigualdade que ocorre entre os envolvidos - empregados e empregadores - nas relações de trabalho. Pode-se mencionar, por fim, que o empregador, em decorrência desta relação jurídica, é detentor de direitos e faculdades que, exercidas de forma inadequada, mostram-se como potenciais fatores de afrontas e violações à liberdade, privacidade e dignidade dos trabalhadores.

Caminhando nessa mesma linha, e para os fins a que se propõe a presente pesquisa, adota-se a teoria da eficácia horizontal direta e imediata dos direitos fundamentais, uma vez que se pretende analisar o papel da negociação coletiva (acordos e convenções coletivas de trabalho) como instrumentos adotados pelas partes (empregados e empregadores) para implementar ações afirmativas da dignidade da pessoa humana (e dos direitos fundamentais que daí emanam) no âmbito das relações de trabalho.

Esse é o objeto da próxima seção. 


\section{A eficácia horizontal direta dos direitos fundamentais no âmbito das relações de trabalho: o papel da negociação coletiva na implementação de ações afirmativas da dignidade do trabalhador}

Cumpre-nos, de início, delinear o conceito de ação afirmativa adotado no presente estudo, vez que aqui se propõe a adoção de conceito mais amplo, com viés privado, que se distingue do sentido público tradicional.

A doutrina tem, tradicionalmente, definido as ações afirmativas como aquelas políticas públicas de discriminação positiva, isto é, as ações estatais coordenadas e deliberadamente voltadas à criação de desigualdade lícita, com o fito de promover a igualdade jurídica entre sujeitos materialmente desiguais. Tal desigualdade pode ser estabelecida na conformação de ação de inclusão e/ou de tratamento compensatório destinados a setores vulneráveis da sociedade (GOLDSCHMIDT, 2009, p. 150-151).

Nesta pesquisa, preferiu-se ampliar o sentido tradicional atribuído às ações afirmativas conforme o proposto por Goldschmidt (2009, p. 151):

$\mathrm{Na}$ verdade, a noção de ações afirmativas que ora se adota tem pretensão mais ampla, já que se trata de afirmar o princípio constitucional da dignidade da pessoa humana e, por via reflexa, proteger a generalidade dos trabalhadores (aí também incluídos segmentos de trabalhadores ainda mais vulneráveis e discriminados como mulheres, envelhescentes e portadores de necessidades especiais) contra os efeitos precarizantes da flexibilização dos direitos trabalhistas.

As ações afirmativas no âmbito do presente estudo são, portanto, entendidas como aquelas ações planejadas, coordenadas e intencionalmente destinadas a garantir, proteger e efetivar a dignidade da pessoa humana no âmbito das relações de trabalho.

A preferência por essa conceituação mais abrangente ocorre em razão do objetivo central desta pesquisa, que é encontrar nas medidas práticas adotadas pelos empregadores e empregados portanto, sujeitos de direito privado - ações de afirmação da dignidade da pessoa humana dos trabalhadores, de tal forma que seja possível afirmar que o empregador age para concretizar o princípio constitucional da dignidade ainda que o Estado se encontre em estado letárgico e não aja nessa direção.

Retomando o tema debatido na primeira seção da presente pesquisa, a dignidade é o fundamento de toda a ordem jurídica brasileira, de forma a irradiar seus efeitos e modular a ação legislativa e administrativa do Estado (eficácia vertical), da mesma maneira que impõe limites à atuação dos indivíduos nas relações intersubjetivas (eficácia horizontal), vinculando a todas as pessoas físicas e jurídicas sem distinção.

Nesse ponto, colhe-se a relevante lição de Ledur (2016, p. 358):

Em realidade, a opção do poder constituinte originário em lançar a base da República Federativa do Brasil em normas fundamentais como a cidadania, a dignidade da pessoa humana e os valores sociais do trabalho e da livre iniciativa, além de atribuir caráter jusfundamental a série de direitos do trabalho, importou 
a transição do centro do sistema de proteção do trabalho da Consolidação das Leis do Trabalho (CLT) para a Constituição. E, do ponto de vista de sua dimensão jurídico-objetiva, os direitos fundamentais possuem função de proteção que se manifesta quando servem como referência interpretativa de regras infraconstitucionais, asseguram proteção em hipóteses em que os conflitos de direito privado revelam grande desequilíbrio entre as partes e irradiam eficácia que alcança os direitos e deveres do trabalhador e do empregador/tomador do trabalho na relação de emprego ou de trabalho (eficácia horizontal).

Assim, a dignidade da pessoa humana, que informa a conformação e a interpretação dos direitos fundamentais, deve ser respeitada, preservada e efetivada pelo Estado, pelos indivíduos e pelos entes coletivos (aqui entendidos não somente os sindicatos - profissional e econômico -, mas, também, as empresas).

Portanto, busca-se aqui identificar ações afirmativas da dignidade da pessoa humana nas relações de trabalho, idealizadas, coordenadas e implementadas por intermédio da negociação coletiva (acordos e convenções coletivas de trabalho), como medida de realização da eficácia horizontal imediata dos direitos fundamentais e concretização da justiça social.

Esse entendimento se evidencia na assertiva de Goldschmidt (2009, p. 150):

E é justamente a afirmação da dignidade da pessoa humana, que fundamenta os direitos trabalhistas, que proporcionará a tão almejada justiça social em nosso país diminuindo a absurda e inaceitável desigualdade social que exclui a grande massa dos cidadãos brasileiros do acesso aos meios básicos de vida digna, como o trabalho a educação e a saúde.

Assim, conforme Goldschmidt (2009), "por 'ações afirmativas da dignidade da pessoa humana' deseja-se designar ações que 'afirmem', ou seja, que tornem firme e eficaz o princípio constitucional da dignidade da pessoa humana" realizadas pelos particulares para sanar a inércia estatal porventura ocorrida.

Toma-se por base, aqui, a concepção de pluralismo jurídico - na qual outros agentes jurídicos, além do Estado, podem e devem desenvolver e implementar medidas afirmativas da dignidade da pessoa humana - como defendido por Goldschmidt (2009, p. 177):

Já o pluralismo jurídico parte da ideia de que existem vários níveis de produção do Direito em uma dada sociedade. Nesse sentido, o Estado seria o maior produtor de fontes jurídicas, por intermédio das leis e da jurisprudência. Todavia o Estado não é o único e exclusivo ente a produzir o Direito; a sociedade civil, por intermédio de suas associações, sindicatos e empresas, também está autorizada a produzir normas estatutárias, convenções coletivas e contratos, instrumentos esses que também possuem força normativa e que sofrem um controle mais ou menos rígido do Estado, de acordo com sua conformação social ou liberal.

A respeito da necessidade da participação da sociedade civil, bem como dos próprios trabalhadores, na efetivação da dignidade da pessoa humana, continua Goldschmidt (2009, p. 158) a asseverar: 
Mas, para que o Estado cumpra o seu papel precípuo e fundamental, inclusive implantando ações afirmativas da dignidade da pessoa humana pela via legislativa e pela via das políticas públicas, corrigindo as citadas discriminações, é necessário que os trabalhadores exerçam sua cidadania, vale dizer, que reivindiquem e lutem por seus direitos tão sofridamente conquistados ao longo da história, exigindo o cumprimento da Constituição, principalmente na afirmação e promoção da dignidade da pessoa humana.

Dessa forma, vê-se como essencial a atuação dos atores privados na promoção, proteção e concretização da dignidade da pessoa humana, agindo em parceria com o Estado - bem como na substituição deste, quando se queda inerte - na elaboração e implementação de políticas tendentes à afirmação do princípio constitucional da dignidade.

A respeito da conceituação de ações afirmativas e sua possibilidade no âmbito da iniciativa privada, manifesta-se Nascimento (2006, p. 381, grifo do autor):

Como entender ações afirmativas? Por se tratar de ações, o seu plano é o sociológico e não o normativo, embora possam neste ser previstas. Mesmo que não o sejam, podem ter existência própria, independentemente de uma fonte legal, uma vez que por serem ações se configuram como realizações. Podem caracterizar-se tanto como ações públicas, quando a sua iniciativa e consecução competem ao Poder Público, quanto como ações privadas, quando surgem por obra de uma inciativa particular desenvolvida por uma entidade que resolve promovê-las, como as ações afirmativas de iniciativa de uma organização não-governamental. Segundo o glossário do Ministério do Trabalho e Emprego, ação afirmativa é uma estratégia de política social ou institucional voltada para alcançar a igualdade de oportunidades entre as pessoas, distinguindo e beneficiando grupos afetados por mecanismos discriminatórios com ações empreendidas em tempo determinado, com o objetivo de mudar positivamente a situação de desvantagem desses grupos.

Empresas e sindicatos profissionais, por meio da negociação coletiva, têm adotado medidas concretas de efetivação, promoção e proteção da dignidade da pessoa humana. Mais que isso: por meio da aludida negociação, empregados e empregadores têm implementado, na prática, ações concretas visando dar efetividade (eficácia horizontal) aos direitos fundamentais dos trabalhadores no âmbito das relações de trabalho.

A esse respeito, ao aludir os processos de "constitucionalismo social", Cataldo (2015) coloca em destaque a liberdade sindical, a negociação coletiva e a eficácia horizontal dos direitos fundamentais, preconizando:

No centro desse constitucionalismo social está, então, a liberdade sindical e a negociação coletiva. Com efeito, "o valor constitucional" da liberdade tem uma qualifica expressão laboral, de dimensão tanto individual como coletiva, na liberdade sindical: um direito este reivindicado pelo movimento obreiro desde sua origem. Reconhecida nas constituições de Querétaro e Weimar e, a partir delas em todo o moderno constitucionalismo, a liberdade sindical supõe um avanço transcendental a partir do simples direito de associação e reunião contemplado nas velhas constituições do século XIX. [...]

Existe ainda outro processo de constitucionalização. A combinação da denominada eficácia normativa das normas constitucionais - particularmente daquelas que estipulam direitos fundamentais - e a eficácia horizontal de ditos direitos entre particulares, particularmente na relação laboral, engatilharam uma segunda cru- 
zada histórica entre a ordem constitucional e o direito do trabalho. (CATALDO, 2015, p. 92). ${ }^{11}$

Conforme anteriormente mencionado, para os fins a que se destina este trabalho, as ações afirmativas que aqui interessam são aquelas de iniciativa privada, consagradas e realizadas no âmbito da negociação coletiva e que têm o objetivo de preservar, promover ou realizar a dignidade da pessoa humana (imprimindo eficácia horizontal aos direitos fundamentais sociais laborais).

A negociação coletiva, por seu turno, nas palavras de Cassar (2011, p. 1313):

Caracteriza-se como fonte de elaboração de normas positivadas, portanto, como fonte material, as negociações coletivas têm como função a criação, modificação ou supressão de condições de trabalho, isto é, sua função é normativa e flexibilizadora. Além disso, se destina à composição de conflitos, logo, também tem função pacificadora, servindo de importante instrumento de redução das demandas judiciais e estabilidade social.

A mencionada autora ainda destaca a função social da negociação coletiva, que se caracteriza "[...] pela participação dos trabalhadores nas decisões empresariais, seja para a harmonia do ambiente social de trabalho seja para a criação de novas e boas condições de trabalho, o que resolve inúmeras questões sociais." (CASSAR, 2011, p. 1313).

Em complemento, de acordo com Uriarte (1996, p. 13): "[...] a negociação coletiva é o instrumento central de harmonização do conflito, de harmonização dos interesses divergentes; e por conseguinte, é o instrumento central de qualquer política de relações industriais." 12

Supiot (2008, p. 64-65) entende que o mercado de trabalho tem sofrido muitas mudanças e está, atualmente, marcado tanto pela diversidade profissional, quanto pela diversidade de trabalhadores e modos individuais de vida. Para o autor, os sindicatos devem adaptar-se à nova e diversa realidade, abarcando a proteção de categorias não tradicionais de trabalhadores, sob pena de enfraquecer cada vez mais sua influência e relevância no mundo do trabalho.

Dessa forma, a atuação dos sindicatos deve servir para garantir e ampliar direitos laborais, mas não apenas estes, devendo ir além para instituir, mediante a negociação coletiva, meios de proteção e promoção da pessoa humana em sua integralidade, reconhecendo a diversidade do comporta-

\footnotetext{
11 No original em espanhol: "En el centro de esse constitucionalismo social está, entonces, la libertad sindical y la negociación colectiva. Em efecto, 'el valor constitucional' de la libertad tiene una cualificada expresión laboral, de dimensión tanto individual como colectiva, em lalibertad sindical: um derecho éste reivindicado por el movimento obrero desde sus orígenes. Reconocida em las Constituciones de Querétaro y Weimer y, a partir de ellas en todo el moderno constitucionalismo, la libertad sindical supone un avance trascendental a partir del simple derecho de associación y reunión contemplado em las viejas constituciones del siglo XIX. [...] Existe además outro processo de constitucionalización. La combinación de la denominada eficacia normativa de las normas constitucionales - particularmente de las que estipulan derechos fundamentales - y de la eficacia horizontal de dichos derechos entre particulares, particularmente a la relación laboral, gatillarán un segundo cruce histórico entre el orden constitucional y el derecho del trabajo."

12 No original, em espanhol: "[...] la negociación colectiva se vuelve un elemento esencial, porque si las dos únicas formas de relacionarse dirección y trabajadores, propietario y sindicato, son el conflicto o La negociación, puesbien, la negociación colectiva es la alternativa alabatalla, la negociación colectiva es la alternativa pacífica."
} 
mento humano, protegendo essa diversidade e garantindo aos trabalhadores e trabalhadoras o pleno exercício de sua identidade pessoal mesmo no seio da relação laboral.

Colocada em destaque a importância da negociação coletiva como instrumento de afirmação da dignidade da pessoa humana, levada a cabo pelo protagonismo das partes envolvidas (empregados e empregadores), cumpre agora adentrar a casuística, colocando em evidência, e de forma exemplificativa, alguns instrumentos negociais que, em primeira análise, procuram dar eficácia horizontal aos direitos fundamentais dos trabalhadores no âmbito das relações de trabalho.

Conforme afirmado na primeira parte deste trabalho, os direitos fundamentais devem servir para garantir a liberdade tanto no plano individual, quanto no coletivo, de maneira a reconhecer a identidade dos trabalhadores e proteger, de forma integral, a sua dignidade. Uma forma eficaz de realizar esse reconhecimento e essa promoção é a negociação coletiva, que produz normas que vinculam as categorias envolvidas no processo negocial e, por serem produzidas por quem está diretamente inserido nas relações de trabalho, tem maior facilidade de compreender as nuances, as potencialidades e as fragilidades do setor laboral.

No setor bancário, a primeira experiência de ação afirmativa negocial nas relações de trabalho que se tem notícia, dando eficácia horizontal direta à dignidade da pessoa humana, é o acordo coletivo da Caixa Econômica Federal 2009/2010, ${ }^{13}$ celebrado com o CONTEC que, ainda que timidamente, já oferecia aporte à implementação da igualdade material para os funcionários envolvidos em relacionamentos homoafetivos.

A Cláusula 14 do supramencionado acordo coletivo trata das ausências justificadas ao trabalho e, em sua alínea "c", faculta ao empregado ausentar-se por oito dias consecutivos na hipótese de falecimento de companheiro(a). O parágrafo terceiro, da mesma cláusula, estende aos empregados que mantenham relacionamento com pessoa do mesmo sexo as vantagens do caput, no que couber. ${ }^{14}$

Da mesma forma, o parágrafo quarto, da Cláusula 18, que trata de licença por adoção e licença paternidade, deixa claro que o benefício será concedido aos funcionários em relações homo-

13 Celebrado pela Caixa Econômica Federal, enquanto empregadora, e pelos empregados representados pela Confederação Nacional dos Trabalhadores nas Empresas de Crédito (2009).

14 CLAÚSULA 14 - AUSÊNCIAS PERMITIDAS

O empregado poderá deixar de comparecer ao serviço, mediante requerimento pessoal à chefia imediata, por motivo de:

a) Casamento, de 8 (oito) oito dias consecutivos a contar da data do evento;

b) Licença paternidade pelo nascimento de filho, de 10 (dez) dias, consecutivos ou não, inclusive o de registro, dentro de 180 (cento e oitenta) dias a contar da data do evento;

c) Falecimento do cônjuge ou de pais, filhos, irmãos e companheiro(a), de 8 (oito) dias consecutivos a contar da data do óbito; d) Falecimento de avós, netos, sogros, genros, noras, ou pessoa devidamente inscrita como sua dependente no órgão de previdência oficial, de 06 (seis) dias consecutivos a contar do óbito;

$[\ldots]$

m) Um dia por ano para internação hospitalar por motivo de doença de cônjuge ou companheiro(a), filho, pai ou mãe; $[\ldots]$

Parágrafo Terceiro - No que couber, as ausências definidas no caput serão concedidas ao companheiro(a) de mesmo sexo. 
afetivas, permitindo o gozo de licença de até 180 (cento e oitenta) dias para os funcionários que adotem crianças de até oito anos de idade. ${ }^{15}$

Desde então, os sindicatos obreiros e patronais vinculados às Cooperativas de Crédito têm adotado medidas de proteção à dignidade da pessoa humana de seus trabalhadores por meio de negociação coletiva. A Convenção Coletiva de Trabalho 2016/201716 celebrada pelo Sindicato dos Empregados em Cooperativas de Crédito do Estado do Rio Grande do Sul e pelo Sindicato Nacional das Cooperativas de Crédito, estabelece a obrigação das cooperativas de crédito de coibir condutas potencialmente violadoras da dignidade do trabalhador quando do estabelecimento e cobrança de objetivos e metas, em sua cláusula décima sexta, sob a rubrica assédio moral, de forma a evitar qualquer conduta, ação ou omissão que resulte em situações constrangedoras, humilhantes, vexatórias ou discriminatórias. ${ }^{17}$

Mesmo sendo obrigação constitucional do empregador a manutenção da saúde e higidez do ambiente de trabalho, a iniciativa de estabelecer, com clareza, uma obrigação da cooperativa de coibir quaisquer práticas abusivas perpetradas entre os seus funcionários na cobrança e estabelecimento de metas é uma forma de concretizar a proteção à dignidade do trabalhador diante da exacerbada avidez pela lucratividade tão marcante do setor financeiro. ${ }^{18}$

Trata-se, nas palavras de Cataldo (2015, p. 104), da assim chamada "constitucionalização do contrato de trabalho":

Desse modo, trabalhador e empresário ficam ligados em uma dupla perspectiva: por um aparte, a relação laboral que lhe liga e que gera uma trama de direitos e obrigações laborais entre eles, e por outro lado, a relação entre dois cidadãos vinculados pelo exercício simultâneo de direitos fundamentais entre eles. Nesse sentido, o processo de recomposição constitucional do contrato de trabalho anunciado pela doutrina fará referência de como deve se solucionar o cruzamento entre ambas as dimensões da relação entre trabalhador e empresário. E esse cruzamento significa a mútua acomodação entre o exercício desses direitos fundamentais por

15 CLÁUSULA 18 - LICENÇA ADOÇÃO/LICENÇA PATERNIDADE

No caso de adoção ou guarda judicial de criança de até 8 anos de idade, a CAIXA concederá licença remunerada ao(à) empregado(a), pelo período de 180 (cento e oitenta) dias.

$[\ldots]$

Parágrafo Quarto - No caso de relação estável com companheiro(a) do mesmo sexo, sendo ambos(as) empregados(as) da CAIXA, exclusivamente um(a) terá direito ao período de licença, podendo o(a) outro(a) usufruir do mesmo período e condições previstas para a licença paternidade.

16 A mencionada Convenção Coletiva de Trabalho foi registrada no Ministério do Trabalho e Emprego sob o número RS 002422/2016, na data de 29 de setembro de 2016, cujo número de processo é 46218.015926/2016 (SINDICATO DOS EMPREGADORES EM COOPERATIVAS DO ESTADO DO RIO GRANDE DO SUL, 2017a).

17 Assédio Moral

CLÁUSULA DÉCIMA SEXTA - ASSÉDIO MORAL

As Cooperativas de crédito convenentes coibirão qualquer conduta, ação ou omissão que resulte em situações constrangedoras, humilhantes, vexatórias ou discriminatórias, de superior hierárquico ou de qualquer outro empregado no ambiente de trabalho, inclusive quando da cobrança de objetivos e de metas.

18 Aqui vale a referência à Súmula 47 do Tribunal Regional do Trabalho da $12^{\text {a }}$ Região - Santa Catarina -, que estabeleceu que o simples estabelecimento de metas abusivas no setor bancário já se configura em dano moral indenizável. SÚMULA N. ${ }^{\circ}$ 47 - "COBRANÇA ABUSIVA DE CUMPRIMENTO DE METAS. DANOS MORAIS. CABIMENTO. Embora regular a fixação e cobrança de metas, o abuso caracteriza dano moral indenizável.” (SANTA CATARINA, 2013). 
parte do trabalhador e o cumprimento de deveres e obrigações laborais provenientes da lei e do contrato de trabalho entre as partes. ${ }^{19}$

Outro exemplo verificado na mesma Convenção Coletiva de Trabalho é a possibilidade de o empregado que mantiver uma relação homoafetiva estável estender ao seu(a) companheiro(a) os benefícios pertinentes aos cônjuges. Tal benefício está disposto na Cláusula Décima Sétima, sob a rubrica política para dependentes. ${ }^{20}$

○ que se percebe, das cláusulas anteriormente mencionadas, é uma ação concreta das cooperativas empregadoras no Rio Grande do Sul, na direção de garantir que seus trabalhadores não sejam expostos a situações de humilhação, constrangimento ou vexação no ambiente de trabalho em razão do estabelecimento e cobrança de metas (que é uma prática legítima), quando estas se configurarem em abusivas, bem como a garantia da igualdade e prevenção à discriminação contra aqueles funcionários que vivenciam a opção sexual homoafetiva, permitindo, inclusive, a extensão dos benefícios pertinentes à categoria de cônjuge aos(às) companheiros(as) como forma de garantir a isonomia material concretamente.

Em outras palavras, e na esteira do que já fora exposto nas linhas pretéritas: a negociação coletiva em tela compatibiliza e protege os direitos fundamentais dos trabalhadores (eficácia horizontal) no âmbito da relação privada laboral.

Digno de nota, contudo, que as cláusulas já mencionadas não constam da Convenção Coletiva de Trabalho 2016/2017, ${ }^{21}$ relativa aos trabalhadores na Confederação Nacional das Cooperativas Centrais Unicreds, ainda que tenham sido firmadas pelos mesmos sindicatos convenentes anteriormente mencionados. $\bigcirc$ que nos leva a concluir que, em que pese a existência de algumas iniciativas vanguardistas e garantidoras da dignidade da pessoa humana do trabalhador, na forma de ações afirmativas, ainda há um longo caminho a percorrer, pois ainda são iniciativas pontuais e não há consenso dentro das mesmas categorias.

$\mathrm{Na}$ esteira das anteriormente indicadas, mais exemplos de ações afirmativas privadas/negociais da dignidade do trabalhador são as encontradas nas cláusulas décima nona e vigésima, da

\footnotetext{
19 No original, em espanhol: "De esse modo, trabajador y empresário quedan ligados desde una doble perspectiva: por una parte, la relación laboral que the liga y que genera um entramado de derechos y obligaciones laborales entre ellos, y por outro lado, la relación entre dos ciudadanos vinculados por el ejercício simultaneo de derechos fundamentales entre ellos. En esse sentido, el proceso de recomposición constitucional del contrato de trabajo anunciado por la doctrina hará referencia a como debe solucionarse el cruce entre ambas dimensiones de la relación entre trabajador y empresario. Y esse cruce significa el mutuo acomodo entre elejercicio de esos derechos fundamentales por parte deltrabajador y el cumplimiento de deberes y obligaciones laborales provenientes de la ley y el contrato de trabajo entre las partes." 20 Política para Dependentes CLÁUSULA DÉCIMA SÉTIMA - RELAÇÃO HOMOAFETIVA

O membro da categorial profissional que mantenha relação homoafetiva estável poderá estender ao companheiro (a) os direitos constantes dessa norma coletiva, não se responsabilizando a Cooperativa empregadora, caso os mesmos não venham a ser reconhecidos por terceiros.

21 A citada Convenção Coletiva de Trabalho 2016/2017 se aplica aos trabalhadores da UNICRED BRASIL - Central Cooperativa das Unicreds, e que reúne as cooperativas singulares UNICRED. Essa Convenção está registrada no Ministério do Trabalho e Emprego sob o número RS002290/2016, datado de 23 de setembro de 2016, processo número 46218.015124/2016 (CONFEDERAÇÃO NACIONAL DAS COOPERATIVAS CENTRAIS UNICREDS, 2017).
} 
Convenção Coletiva de Trabalho 2016/2017,22 relativa aos empregados nas Cooperativas de Crédito Mútuo Sicredi no Rio Grande do Sul e em Santa Catarina.

Ainda que sejam mais restritivas, as garantias encontradas na referida Convenção Coletiva de Trabalho também podem ser entendidas como medidas concretas de promoção e efetivação da dignidade do trabalhador, mediante o estabelecimento da obrigação de coibir a humilhação na cobrança de metas e da proibição da discriminação (efetivação do princípio da isonomia), conforme se depreende das cláusulas Décima Nona e Vigésima. ${ }^{23}$

O que se verifica, então, é a ação privada/negocial que atua na lacuna deixada pelo poder público para garantir a dignidade do trabalhador e promover a igualdade e o respeito no ambiente de trabalho.

Tome-se ainda como exemplo de ação afirmativa privada/negocial da dignidade da pessoa humana, dando eficácia horizontal direta dos direitos fundamentais sociais nas relações de trabalho, a Convenção Coletiva de Trabalho 2015/2016 ${ }^{24}$ relativa aos trabalhadores em instituições financeiras celebrada entre a Federação Nacional dos Bancos (Fenaban), e a Confederação Nacional dos Trabalhadores no Ramo Financeiro (Contraf).

A norma coletiva garante, sob o título de cláusulas relativas à diversidade, na cláusula 48a, a igualdade de oportunidades e cria uma Comissão Bipartite para desenvolver propostas de orientação aos empregados, gestores e empregadores com o objetivo de prevenir posturas discriminatórias nos ambientes de trabalho e na sociedade em geral.

A mesma cláusula 48 , em seu parágrafo primeiro, cria o Programa FEBRABAN de Valorização da Diversidade no Setor Bancário e o Programa FEBRABAN de Capacitação Profissional e Inclusão Social de Pessoas com Deficiência do Setor Bancário. ${ }^{25}$

\footnotetext{
22 A Convenção Coletiva de Trabalho 2016/2017 foi firmada pelo Sindicato dos Empregados de Cooperativas de Crédito do Estado do Rio Grande do Sul e pelo OCERGS-Sindicato e Organização das Cooperativas do Estado do RS. Está registrada no Ministério do Trabalho e Emprego sob o número RS 002346/2016, na data de 26 de setembro de 2016, no processo número 46218.015322/2016 (SINDICATO DOS EMPREGADOS EM COOPERATIVAS DE CRÉDITO DO ESTADO DO RIO GRANDE DO SUL, 2017b).

${ }^{23}$ Assédio Moral

CLÁUSULA DÉCIMA NONA - ASSÉDIO MORAL NO LOCAL DE TRABALHO

As cooperativas de crédito coibirão situações constrangedoras, humilhantes, vexatórias e discriminatórias promovidas por superior hierárquico ou outro empregado, bem como não exercerão pressão excessiva na cobrança de metas.

Política para Dependentes

CLÁUSULA VIGÉSIMA - RELAÇÃO HOMOAFETIVA

As vantagens desta Convenção Coletiva de Trabalho aplicáveis aos cônjuges dos empregados, é extensiva aos casos em que a união decorra de relação homoafetiva estável, devidamente comprovada por registro em cartório.

Parágrafo Único

O reconhecimento da relação homoafetiva estável dar-se-á com o atendimento a iguais requisitos observados pela Previdência Social, consoante disciplinam o artigo 45 da Instrução Normativa INSS/PRES. n 45, de 06.08.2010 (DOU de 11.08.2010).

${ }^{24}$ A referida Convenção Coletiva de Trabalho foi celebrada em 03 de novembro de 2015 e teve vigência entre 01 de setembro de 2015 e 31 de agosto de 2016, e abrange os empregados vinculados aos estabelecimentos bancários em todos os estados do Brasil e no Distrito Federal (FEDERAÇÃO NACIONAL DOS BANCOS, 2016).

25 DIVERSIDADE

CLÁUSULA 48 ${ }^{a}$ IGUALDADE DE OPORTUNIDADES

As partes ajustam entre si a manutenção da Comissão Bipartite que desenvolverá propostas de orientação a empregados, gestores e empregadores no sentido de prevenir eventuais distorções que levem a atos e posturas discriminatórias nos ambientes de trabalho e na sociedade de forma geral.
} 
Assim, o que se percebe é a norma coletiva estabelecendo a criação de mecanismos de prevenção à discriminação no mercado de trabalho, da mesma forma que cria programas de valorização da diversidade e inclusão de pessoas com deficiência no setor bancário, afirmando, dessa maneira, a dignidade da pessoa humana, em um claro exemplo de eficácia horizontal dos direitos fundamentais do trabalhador promovido pela iniciativa privada/negocial.

O mencionado diploma laboral coletivo vai mais além e, em sua cláusula 49a , concretiza a isonomia entre todos os empregados ao conceder, taxativamente, aos funcionários que vivem em relação homoafetiva os mesmos benefícios relativos aos cônjuges. ${ }^{26}$

A Convenção Coletiva 2016/2018 dos Trabalhadores em Cooperativas de Crédito do Estado de São Paulo ${ }^{27}$ também prevê medidas concretas que promovam a igualdade e combatam a discriminação no ambiente de trabalho, afirmando, na esteira da chamada eficácia horizontal dos direitos fundamentais, a dignidade do trabalhador, conforme se verifica das cláusulas transcritas a seguir:

Merece destaque, na Convenção Coletiva mencionada, a determinação da realização de aferição da eficácia das ações afirmativas da dignidade da pessoa humana no âmbito privado das relações de trabalho, mediante o que se denomina "Auditoria da Diversidade" que deve se realizar em até seis meses após a assinatura do diploma coletivo. ${ }^{28}$

\footnotetext{
Parágrafo Primeiro

O Programa FEBRABAN de Valorização da Diversidade no Setor Bancário e o Programa FEBRABAN de Capacitação Profissional e Inclusão Social de Pessoas com Deficiência do Setor Bancário servirão de premissa para orientação dos bancos na implementação de suas ações, de acordo com as diretrizes e planos de ação definidos ou que vierem a ser definidos no Programa. Parágrafo Segundo

A Comissão Bipartite de Igualdade de Oportunidades realizará reuniões trimestrais para acompanhamento do Programa de Valorização da Diversidade.

26 CLÁUSULA 49ª EXTENSÃO DE VANTAGENS - RELAÇÃO HOMOAFETIVA

As vantagens desta Convenção Coletiva de Trabalho aplicáveis aos cônjuges dos empregados abrangem os casos em que a união decorra de relação homoafetiva estável, devidamente comprovada.

Parágrafo Primeiro

O reconhecimento da relação homoafetiva estável dar-se-á com o atendimento a iguais requisitos observados pela Previdência Social, consoante disciplinam o art. 45 da Instrução Normativa INSS/PRES. nº 45, 06.08.2010 (D.O.U de 11.08.2010).

Parágrafo Segundo

$\mathrm{Na}$ vigência da presente Convenção Coletiva de Trabalho os bancos divulgarão, internamente, as vantagens de que trata o caput desta cláusula e determinarão que a opção do(a) empregado(a) será feita diretamente à área de Recursos Humanos.

27 Celebrada entre a Confederação Nacional dos Trabalhadores do Ramo Financeiro (Contraf), a Federação dos Trabalhadores em Empresas de Crédito do Estado de São Paulo, a Federação dos Empregados em Estabelecimentos Bancários do Estado de São Paulo e Mato Grosso do Sul, o Sindicato dos Empregados em Estabelecimentos Bancários de São Paulo e o Sindicato das Cooperativas do Estado de São Paulo, em 26 de outubro de 2016, e que abrange a categoria dos empregados em cooperativas de crédito do Estado de São Paulo (CONFEDERAÇÃO NACIONAL DOS TRABALHADORES DO RAMOS FINANCEIRO, 2018).
}

28 CLÁUSULA 28: PROMOÇÃO DA IGUALDADE DE OPORTUNIDADE DE TRATAMENTO PARA TODOS E TODAS

As Cooperativas abrangidas por esta convenção se comprometem a desconstituir o quadro de desigualdades entre seus empregados, de modo que a proporção de negros, mulheres e pessoas com deficiência, nas empresas, em até 02 (dois) anos, seja semelhante à proporção desses grupos na PEA de cada Estado.

PARÁGRAFO ÚNICO: A execução dessa política de Promoção da Igualdade será acompanhada pelo Sindicato dos Empregados.

CLÁUSULA 29: ISONOMIA DE TRATAMENTO PARA HOMOAFETIVOS

As vantagens legais, convencionais ou contratuais que se aplicam aos parceiros (as) de empregados (as) abrangidos por esta convenção, serão também aplicáveis aos casos em que a relação de união civil decorra de relacionamento homoafetivo, considerando-se para todos os efeitos a mesma condição de cônjuges.

PARÁGRAFO PRIMEIRO: A comprovação da condição de parceiro (a) se dará com fulcro nos princípios da Constituição Federal e legislação infraconstitucional aplicável para os casais heterossexuais. 
Ainda que não se estabeleça punição para a cooperativa que não atinja níveis aceitáveis de diversidade e igualdade, a determinação de apuração de tais níveis, por si só, já se configura em ação concreta, de iniciativa privada/negocial, indicativa da relevância da necessidade de afirmação da dignidade da pessoa humana do trabalhador.

Diante dos exemplos colacionados pode-se afirmar a existência e a relevância de ações afirmativas empresariais da dignidade da pessoa humana no âmbito das relações de trabalho, como elementos de concretização dessa mesma dignidade. Tais ações são realizadas pelos particulares na ausência, ou como complemento, de medidas similares elaboradas e implementadas pelo Estado, configurando-se em elementos essenciais à efetivação dos ideais democráticos de igualdade e dignidade da pessoa humana, na assim chamada eficácia horizontal dos direitos fundamentais.

\section{Conclusões}

À guisa de conclusão, é seguro afirmar que a dignidade da pessoa humana assume primazia no ordenamento jurídico brasileiro. A própria existência da República Federativa brasileira fundamenta-se na dignidade da pessoa humana.

Dessa forma, esse relevante princípio constitucional irradia seus efeitos para todo o ordenamento jurídico, impondo ao legislador infraconstitucional elaborar as leis, e ao aplicador jurídico interpretá-las, em conformidade com seus ditames.

Essa irradiação de efeitos impõe-se não somente aos agentes públicos, produzindo efeitos, mas também nas relações entre particulares.

Dentre as teorias de produção da eficácia dos direitos fundamentais entre particulares, existem aquelas que negam e as que afirmam, de forma direta ou indireta.

PARÁGRAFO SEGUNDO: No caso de adoção por casal homoafetivo, deverão ser observadas as mesmas garantias estabelecidas para os casais heterossexuais.

CLÁUSULA 30: PROMOÇÃO DA DIVERSIDADE

As cooperativas abrangidas por esta convenção realizarão Auditoria da Diversidade entre os seus empregados, devendo iniciar-se em até 06 (seis) meses da data assinatura deste instrumento normativo.

PARÁGRAFO ÚNICO: As cooperativas comprometem-se com o Sindicato dos Empregados em debater a instituição de mecanismos para estimular a adoção de Programas de Promoção da Diversidade, seja através de programas educativos, seja por meio de quaisquer outros métodos adequados às circunstâncias, que visem promover a igualdade de oportunidades e de tratamento em matéria de emprego e profissão.

CLÁUSULA 31: CONTRATAÇÃO DE TRABALHADORES COM DEFICIÊNCIA

As cooperativas abrangidas por esta convenção viabilizarão a contratação de pessoas com deficiências, combatendo a discriminação e proporcionando seu desenvolvimento.

CLÁUSULA 32: MEDIDAS DE PREVENÇÃO AO ASSÉDIO MORAL E/OU ASSÉDIO SEXUAL

As cooperativas abrangidas por esta convenção se comprometem a dar início à campanha de prevenção e combate ao assédio moral e sexual no local de trabalho, em conjunto com o Sindicato dos Empregados, devendo:

a) Promover por meio das CIPAS e sindicatos, palestras e debates nos locais de trabalho;

b) Publicar obras específicas;

c) Disponibilizar mural e quadro de avisos ao Sindicato dos Empregados, para que possam afixar cartazes e divulgar eventos;

d) Estabelecer calendário de reuniões nas cooperativas.

PARÁGRAFO ÚNICO: O Sindicato dos Empregados deverá ser comunicado sobre quaisquer denúncias de assédio moral e/ou sexual, devendo ter acesso a toda a investigação e acompanhamento das eventuais punições. 
A posição adotada na presente pesquisa é a que preconiza a eficácia horizontal direta e imediata, qual seja, aquela que determina a incidência dos direitos fundamentais nas relações intersubjetivas sem que haja necessidade da mediação do Estado através de sua atividade legislativa.

Essa eficácia horizontal direta e imediata também se traslada às relações de trabalho, impondo aos seus participantes o respeito, a promoção e a concretização da dignidade da pessoa humana dos trabalhadores.

O empregador, vinculado à eficácia horizontal direta dos direitos fundamentais não pode, a pretexto de maximizar seus lucros - ainda que queira fundamentar essa sua pretensão em outro direito fundamental, o da propriedade privada - agir em detrimento da condição de sujeito de direitos dos seus trabalhadores, e, assim, estabelecer condições de trabalho que tenham o condão de vulnerabilizar o empregado.

Como resultado direto da desigualdade existente entre empregador e empregado - isto é, a subordinação jurídica e econômica -, surge a obrigação estatal de promover medidas que tenham o condão de minorar a desigualdade e alcançar desejáveis patamares de igualdade. Nem sempre o Estado se desincumbe satisfatoriamente desse ônus.

É nesse contexto que surgem as ações afirmativas privadas da dignidade da pessoa humana que, neste trabalho, são entendidas como políticas públicas privadas que têm o objetivo de diminuir a desigualdade e promover, de forma concreta, a dignidade da pessoa humana do trabalhador.

Ditas ações afirmativas privadas podem realizar-se, no mundo do trabalho, por meio da atuação das entidades sindicais patronais e obreiras que, na qualidade de entidades representativas, buscam proteger e promover os interesses da categoria que representam.

No processo negocial laboral as partes envolvidas têm o dever de colaborar para o sucesso da negociação, agindo de boa-fé e em lealdade. $O$ ato de negociar as condições de trabalho, necessariamente, deve se pautar pela garantia da dignidade da pessoa humana do trabalhador. E tal dignidade não está adstrita às normas de desenvolvimento e execução do trabalho, mas abrange a pessoa do trabalhador considerada em sua integralidade, diversidade e identidade.

A negociação coletiva pode, portanto, tornar-se (além de conjunto de regras atinentes à prestação de trabalho) tanto instrumento de prevenção, combate e eliminação da discriminação, quanto meio de garantia, de forma ampla e irrestrita, da dignidade da pessoa humana do trabalhador, e é nessa perspectiva que foi apresentada no presente trabalho de pesquisa.

Foram aqui apresentados alguns exemplos de ações afirmativas privadas, dispostas em acordos e convenções coletivas de trabalho relativas aos trabalhadores em instituições financeiras e cooperativas de crédito. Tais ações estão configuradas como medidas tendentes à eliminação do preconceito contra os trabalhadores em relacionamentos homoafetivos, mediante a extensão dos direitos atinentes aos cônjuges heterossexuais, bem como ao estabelecimento de práticas de combate à discriminação e de promoção da igualdade e da diversidade no ambiente de trabalho. 
Tais ações afirmativas privadas constituem-se em forma concreta de afirmar a eficácia horizontal imediata dos direitos fundamentais dos trabalhadores, e configuram-se em elementos essenciais para a promoção e efetivação dos ideais democráticos da igualdade e dignidade da pessoa humana nas relações de trabalho.

\section{Referências}

ALEXY, Robert. Constitutional Rights, balancing and rationality. Ratio Juris, v. 16, n. 2, p. 131-140, June 2003.

ALEXY, Robert. Teoria dos direitos fundamentais. Tradução Vírgilo Afonso da Silva. 2. ed. São Paulo: Malheiros Editores, 2011. Tradução de: Theorie der Grundrechte.

AMARAL, Júlio Ricardo de Paula. Os direitos fundamentais e a constitucionalização do direito do trabalho. In: MONTESSO, Cláudio José; FREITAS, Marco Antônio de; STERN, Maria de Fátima Coêlho Borges (Coord.). Direitos Sociais na Constituição de 1988: Uma análise crítica vinte anos depois. São Paulo: Ltr, 2008.

ANDRADE, José Carlos Vieira de. Os direitos fundamentais na Constituição Portuguesa de 1975. 3. ed. Coimbra: Almedina, 2004.

BARBAGELATA, Héctor-Hugo. Curso sobre la evolución del pensamento juslaboralista. Montevidéo/ Uruguai: Editora Fundación de Cultura Universitaria, 2009.

CANOTILHO, José Joaquim Gomes. Direito Constitucional. 5. ed. Coimbra: Almedina, 1991.

CASSAR, Vólia Bomfim. Direito do trabalho. 5. ed. Niterói: Impetus, 2011.

CATALDO, José Luis Ugarte. Derechos fundamentales y trabajo. In: DELGUE, Juan Raso (Dir.).; CASTELLO, Alejandro (Coord.). Derecho del trabalho. 2. ed. Montevideo: Fundación de Cultura Universitaria, 2015. Tomo I.

CONFEDERAÇÃO NACIONAL DAS COOPERATIVAS CENTRAIS UNICREDS. Convenção Coletiva de Trabalho 2016/2017. Disponível em: <http://www.secocrs.org.br/acordos-e-convencoes/12>. Acesso em: 18 abr. 2017.

CONFEDERAÇÃO NACIONAL DOS TRABALHADORES DO RAMO FINANCEIRO. Convenção Coletiva de Trabalho 2016/2018. Disponível em: <http://spbancarios.com.br/sites/default/files/cct/ arquivo/1188_cct_cooperativas_2016_2018.pdf>. Acesso em: 19 abr. 2017.

CONFEDERAÇÃO NACIONAL DOS TRABALHADORES EM EMPRESAS DE CRÉDITO. Convenção Coletiva de Trabalho 2009/2010. Disponível em: <https://www.contec.org.br/attachments/ CEF/ACT/ACT_20092010_CONTECCEF_assinado.pdf>. Acesso em: 19 abr. 2017.

FEDERAÇÃO NACIONAL DOS BANCOS. Convenção Coletiva de Trabalho 2015/2016. Disponível em: <https://cmsportal.febraban.org.br/Arquivos/documentos/PDF/CCT\%20-\%20CONTRAF. pdf>. Acesso em: 19 abr. 2017. 
GOLDSCHMIDT, Rodrigo. Flexibilização dos direitos trabalhistas: Ações afirmativas da dignidade como forma de resistência. São Paulo: LTr, 2009.

HESSE, Konrad. Elementos de Direito Constitucional da República Federal da Alemanha. Tradução Luís Afonso Heck. Porto Alegre: Fabris, 1998.

HESSE, Konrad. Temas fundamentais do direito constitucional. Tradução Carlos dos Santos Almeida, Gilmar Ferreira Mendes e Inocêncio Martires Coelho. São Paulo: Saraiva, 2009.

LEDUR, José Felipe. Direitos fundamentais sociais: efetivação no âmbito da democracia participativa. Porto Alegre: Livraria do Advogado, 2009.

LEDUR, José Felipe. Fundamentos dos direitos da personalidade do trabalhador: algumas reflexões. Revista do Tribunal Regional do Trabalho da $12^{a}$ Região, Florianópolis: TRT12, v. 19, n. 28, p. 357-371, 2016.

LUÑO, Antonio-Enrique Pérez. Los derechos fundamentales. 8. ed. Madrid: Tecnos, 2005.

MARMELSTEIN, George. Curso de direitos fundamentais. 5. ed. rev., atual. e ampl. São Paulo: Atlas, 2014.

MIRANDA, Jorge. Manual de direito constitucional: direitos fundamentais. 5. ed. Coimbra: Coimbra Editora, 2012. Tomo IV.

NASCIMENTO, Amauri Mascaro. Curso de direito do trabalho. 21. ed. rev. e atual. São Paulo: Saraiva, 2006.

NOVAIS, Jorge Reis. Direitos Fundamentais: trunfos contra a maioria. Coimbra: Coimbra Editora, 2006.

SANTA CATARINA. Tribunal Regional do Trabalho de Santa Catarina - $12^{a}$ Região. Súmula n. ${ }^{\circ}$ 47. "Cobrança abusiva de cumprimento de metas. danos morais. cabimento. Embora regular a fixação e cobrança de metas, o abuso caracteriza dano moral indenizável." Diário Oficial Eletrônico, 03, 04 e 05 set. 2013. Disponível em: < http://trtapl3.trt12.gov.br/cmdg/img_legis/2013/08261547. pdf>. Acesso em: 18 abr. 2017.

SARLET, Ingo Wolfgang. A eficácia dos direitos fundamentais: Uma teoria geral dos direitos fundamentais na perspectiva constitucional. 10. ed. rev. e ampl. 3. tir. Porto Alegre: Livraria do Advogado Editora, 2011a.

SARLET, Ingo Wolfgang. Dignidade da pessoa humana e direitos fundamentais na Constituição Federal de 1988. 9. ed. rev. e atual. Porto Alegre: Livraria do Advogado Editora, 2011b.

SARMENTO, Daniel. Dignidade da pessoa humana: conteúdo, trajetórias e metodologia. Belo Horizonte: Fórum, 2016.

SINDICATO DOS EMPREGADOS EM COOPERATIVAS DO ESTADO DO RIO GRANDE DO SUL et al. Convenção Coletiva de Trabalho 2016/2017a. Disponível em: <http://www.secocrs.org.br/ acordos-e-convencoes/2>. Acesso em: 18 abr. 2017. 
SINDICATO DOS EMPREGADOS EM COOPERATIVAS DE CRÉDITO DO ESTADO DO RIO GRANDE DO SUL. Convenção Coletiva de Trabalho 2016/2017b. Disponível em: <http://www. secocrs.org.br/acordos-e-convencoes/4>. Acesso em: 18 abr. 2017.

SIQUEIRA, Rodrigo Espiúca dos Anjos; WENCZENOVICZ, Thais Janaína. A eficácia horizontal imediata dos direitos fundamentais nas relações de trabalho, na jurisprudência do Tribunal Regional do Trabalho da $12^{a}$ Região (Santa Catarina). Revista do Tribunal Regional do Trabalho da $12^{a}$ Região, v. 19, n. 28, p. 373-397, 2016.

SIQUEIRA, Rodrigo Espiúca dos Anjos; WENCZENOVICZ, Thais Janaína. A eficácia horizontal dos direitos fundamentais na jurisprudência do Tribunal Regional do Trabalho da 4 a Região (Rio Grande do Sul). In: SILVA, Leonardo Rabelo de Matos; BARBATO, Maria Rosaria; SCHWARZ, Rodrigo Garcia. Direito do Trabalho e meio ambiente do trabalho II. Florianópolis: CONPEDI, 2016. p. 290-310.

SIQUEIRA, Rodrigo Espiúca dos Anjos; WENCZENOVICZ, Thais Janaína. A eficácia horizontal dos direitos fundamentais na jurisprudência do Tribunal Regional do Trabalho da $9^{a}$ Região (Paraná). In: OLIVEIRA, Francisco Cardozo; DARCANCHY, Mara. Eficácia de direitos fundamentais nas relações de trabalho, sociais e empresariais II. Florianópolis: CONPEDI, 2017. p. 202-222.

STEINMETZ, Wilson. A vinculação dos particulares a direitos fundamentais. São Paulo: Malheiros Editores, 2004.

SUPIOT, Alain. El Derecho del trabajo. 1. ed. Buenos Aires: Heliasta, 2008.

URIARTE, Oscar Ermida. Curso introductorio de relaciones laborales. Montevideo: Fundación de Cultura Universitaria, 1996.

Data da submissão: 02 de julho de 2017 Avaliado em: 06 de julho de 2017 (AVALIADOR A) Avaliado em: 03 de julho de 2017 (AVALIADOR B) Avaliado em: 10 de julho de 2017 (AVALIADOR D) Aceito em: 26 de setembro de 2017 
